\title{
Програма превентивної фізичної реабілітації вертеброгенних порушень шийного відділу для дзюдоїстів
}

\author{
удК 796.853.23:616.8-009.1-085 \\ О. Б. Лазарєва, В. Є. Куропятник
}

Національний університет фізичного виховання і спорту України, Київ, Україна

\begin{abstract}
Резюме. Постановка проблеми. На сьогодні олімпійський спорт має тенденції видовищності та гонки за результатами, що відсуває на задній план першочергові завдання: здоров'я та розвиток особистості. Для єдиноборців це супроводжується підвищенням рівня травматизму і що гірше - розвитком хронічних порушень, а саме дегенеративно-дистрофічних захворювань хребта. Аналіз останніх досліджень і публікацій. Швидкість розвитку програм спортивної підготовки значно відстає від тенденції змін змагальності, а також загального суспільного розвитку. Саме тому в дзюдо постало питання збереження спортивних резервів, а також вдосконалення програм підготовки борців різного віку за рахунок залучення засобів фізичної реабілітації. Мета даної роботи - структуризація програми превентивної фізичної реабілітації вертеброгенних порушень шийного відділу для дзюдоїстів. Результати дослідження. Ми розглядаємо превентивну фізичну реабілітацію як технологію корекційно-профілактичного процесу для дзюдоїстів із застосуванням методів і засобів фізичної реабілітації. За рахунок даних емпіричних методів дослідження та контент-аналізу історій розвитку вертеброгенних порушень у спортсменів високого класу, тренерів і тих людей, котрі вже закінчили спортивну кар'єру, було встановлено потребу розділити програму на загальний та поглиблений компоненти. Висновок. У роботі представлено структуру програми превентивної фізичної реабілітації вертеброгенних порушень шийного відділу для дзюдоїстів, зазначено загальні задачі, спрямування та можливості її впровадження. Висвітлено загальний компонент програми. Ключові слова: дзюдо, спорт, превентивна фізична реабілітація, програма спортивної підготовки.
\end{abstract}

\begin{abstract}
Резюме. Постановка проблемы. На сегодняшний день олимпийский спорт имеет тенденции зрелищности и гонки за результатами, что смещает на задний план первоочередные задач: здоровье и развитие личности. Для борцов это сопровождается повышением уровня травматизма и что хуже - развитием хронических нарушений, а именно дегенеративнодистрофических заболеваний позвоночника. Анализ последних исследований и публикаций. Скорость развития программ спортивной подготовки значительно отстает от тенденции изменений состязательности. Именно поэтому в дзюдо встал вопрос сохранения спортивных резервов, а также совершенствования программ подготовки борцов разного возраста за счет привлечения средств физической реабилитации. Цель данной работы - структурирование программы превентивной физической реабилитации вертеброгенных нарушений шейного отдела для дзюдоистов. Результаты исследования. Мы рассматриваем превентивную физическую реабилитацию как технологию коррекционно-профилактического процесса для дзюдоистов с использованием методов и средств физической реабилитации. За счет данных эмпирических методов исследования и контент-анализа историй развития вертеброгенных нарушений у спортсменов высокого класса, тренеров и лиц, которые уже закончили спортивную карьеру, была установлена необходимость разделить программу на общий и углубленный компоненты. Вывод. В работе представлена структура программы превентивной физической реабилитации вертеброгенных нарушений шейного отдела для дзюдоистов, указаны общие задачи, направления и возможности ее применения. Освещен общий компонент программы.
\end{abstract}

Ключевые слова: дзюдо, спорт, превентивная физическая реабилитация, программа спортивной подготовки.

Abstract. Formulation of the problem. Today, the Olympic sport has a tendency of entertainment and rush towards the results, which shifts the major tasks to the background: health and personal development. In wrestlers it is accompanied by increased levels of accidents and what is worse - the development of chronic disorders, namely degenerative diseases of the spine. Analysis of recent studies and publications. The rate of development of sports training programs is far behind the 
trends of competitiveness changes. That is why the question of maintaining sports reserves in judo as well as improvement of training programs for wrestlers of all ages through the involvement of physical rehabilitation has come up. Objective of the given work - structuring programs for preventive physical rehabilitation of the cervical vertebral disorders in judokas. Results of studies. We consider preventive physical rehabilitation as a technology of corrective and preventive process for judokas, using methods and means of physical rehabilitation. Due to the data of empirical research methods and content analysis of the cases of vertebral disorders in high-class athletes, coaches and officials who have already withdrawn, the necessity to divide the program into general and in-depth components has been determined. Conclusion. The paper presents the structure of the program of preventive physical rehabilitation of cervical vertebral disorders in judokas, the overall objectives, directions and possibilities of its application are given. General program component is highlighted.

Keywords: judo, sport, preventive physical rehabilitation, sports preparation program.

Постановка проблеми. Олімпійський спорт постійно видозмінюється залежно від поколінь і вподобань. Як і будь-який прогрес, він має свої переваги та недоліки. На сучасному етапі свого розвитку, у русі до комерціалізації та бажання видовища під час змагань, все частіше губляться ідеали олімпізму та принципи збереження здоров'я спортсменів як носіїв фенотипу людства.

Для єдиноборств, зокрема для дзюдо, характерно, що спортсмени більшою мірою особисто несуть відповідальність за змагальний результат, що $€$ відображенням у них високого рівня морально-вольових якостей. На хвилі куражу вони отримують такі ураження, які супроводжують їх протягом життя.

Порушення постави характерні для багатьох видів спорту. Але у дзюдоїстів симптоми захворювань хребта спочатку не помітні, а проявляються з часом, коли стає складно виправити заподіяну шкоду. Найбільш уразливими зонами у борців $\epsilon$ поперек, проблеми в якому стають помітними під час інтенсивних фрізичних навантажень, що потребує застосування профрілактичних засобів, і шийний відділ, у якому остеохондроз розвивається латентно, на що відповідно ніяк не реагують.

Програма спортивної підготовки 3 дзюдо, хоча і включає деякі профрілактичні засоби, загалом спрямована на досягнення спортивних результатів шляхом виконання специфічного фрізичного навантаження. Але для збереження здоров'я і гармонійного розвитку спортсмена потрібна злагоджена робота всього організму, що й буде визначати результативність. Тому впровадження методики превентивної фрізичної реабілітації сприятиме не лише вирішенню проблеми збереження спортивного ресурсу, а й покращенню результатів змагальної діяльності.

Незважаючи на великий арсенал методів i засобів, впровадження методик фрізичної реабілітації у програму спортивної підготовки 3 дзюдо - непростий і багатоетапний процес. Складність полягає у специфріці тренувальних занять і технічного арсеналу, що зумовлює особливу структуризацію реабілітаційного процесу. Також потрібно враховувати вікові норми, етапи формування постави, сензитивні періоди розвитку фрізичних якостей і особливості тренувальних циклів.

Аналіз останніх досліджень і публікацій. 3 появою категорії «безпечний рівень здоров'я» було сформульовано поняття «превентивна фрізична реабілітація» $[1,10]$, під яким необхідно розуміти повернення індивіда у безпечну зону здоров'я. Проблема профрілактики та корекції порушень і травм зв'язкових та нервових структур хребта у спортсменів $€$ однією 3 найважливіших для досягнення найвищого спортивного результату, продовження змагальної діяльності та профрілактики виникнення захворювань після завершення спортивної кар'єри [5].

Індуковані травмою або постійним напруженням м'язово-зв'язкового апарату дегенеративні зміни шийного відділу хребта можуть спричинювати вертеброгенні неврологічні ускладнення як центральної (порушення кровообігу у вертебробазилярному басейні), так і перифреричної нервової системи. Вони представлені цервікалгіями, цервікобрахіалгіями, плечо-лопатковим періартрозом [4], які порушують якість життя, обмежуючи фрізичні, функціональні та психологічні можливості людей [11], а для спортсменів це означає зниження результативності тренувальної та змагальної діяльності.

Аналіз науково-методичної літератури показав, що сучасна фрізична реабілітація збагачена великим арсеналом засобів і методів, які застосовують у разі травматичних уражень хребта у спортсменів [8, 12], для відновлення статичного та динамічного стереотипів [6, 13], корекції постави спортсменів різного віку $[9,3]$, фрізичної реабілітації при нефіксованих порушеннях опорно-рухового апарату [2, 14].

На жаль, загальноприйняті програми фрізичної реабілітації для людей із вертеброгенними синдромами шийного відділу не можуть бути адаптовані до тренувального процесу діючих 
спортсменів та впроваджені в річний цикл підготовки у зв'язку з особливостями впливу корекційних вправ на техніку виконання змагальних елементів, що потребує специфрічного підходу впровадження.

Мета даної роботи - структуризація програми превентивної фрізичної реабілітації вертеброгенних порушень шийного відділу для дзюдоїстів.

Методи дослідження: теоретичні - аналіз і синтез науково-методичної літератури, інтернет-ресурсів, вітчизняних і зарубіжних програм підготовки спортсменів-єдиноборців, вивчення історій диспансерних карт дзюдоїстів; емпіричні - вивчення й узагальнення досвіду роботи тренерів, перевірка відповідності реабілітаційних заходів для спортсменів різного віку.

Зв'язок роботи 3 науковоми програмами, планами, темами. Дослідження виконувалось відповідно до Зведеного плану НДР у сорері фрізичної культури і спорту на 2011-2015 рр. за темою 4.4 «Удосконалення організаційних і методичних основ програмування процесу фрізичної реабілітації при дисфункціональних порушеннях у різних системах організму людини» (номер держреєстрації 0111U001737) та відповідно до плану НДР кафедри фрізичної реабілітації НУФВСУ за темою 4.2. «Організаційні та теоретико-методичні основи фрізичної реабілітації осіб різних нозологічних, професійних та вікових груп» (номер держреєстрації 0116U001609).

Результати дослідження та їх обговорення. Превентивна фрізична реабілітація являє собою діяльність, спрямовану на відновлення та закріплення рівня здоров'я організму людини. Ми розглядаємо іï як технологію корекційно-профрілактичного процесу для дзюдоїстів із застосуванням методів і засобів фрізичної реабілітації.

Розробка програми превентивної фрізичної реабілітації дзюдоїстів відбувалася поетапно та спиралась на поточні дані емпіричних методів дослідження та контент-аналізу історій розвитку вертеброгенних порушень у спортсменів високого класу, тренерів та тих людей, які вже закінчили спортивну кар'єру (рис. 1).

Основним фрактором фрормування вертеброгенних порушень шийного відділу хребта у дзюдоїстів $€$ перенапруження м'язів спини та шиї з одночасним ротаційним навантаженням на хребет, що найчастіше супроводжується незначними, а інколи й тяжкими травмами шиї.

Першочерговим завданням програми превентивної фрізичної реабілітації було зменшення м'язового перенавантаження для дзюдоїстів, особливо у сензитивні періоди фрормування постави. Так до тренувального процесу для борців було включено комплекс лікувальної гімнастики [7], завданнями якого були:

- зменшити напруженість м'язів спини та шиї після тренування;

- активізувати м'язи, що забезпечують правильну поставу;

- навчити правильному диханню під час виконання вправ лікувально-профрілактичного спрямування;

- створити мотивацію для фрормування звички постійно виконувати превентивні реабілітаційні заходи.

Дана частина превентивної фрізичної реабілітації була представлена у формі лікувальної гімнастики із використання дихальних і гімнастичних фрізичних вправ спеціального спрямування: на розслаблення м'язів спини та шиї, на розтягнення м'язів плечового поясу, для тракції хребта, для м'язів черевного преса, а також асиметричні вправи для постави. Комплекс лікувальної гімнастики виконувався після завершення тренування дзюдоїстів протягом 10-15 хв, не подовжуючи загального часу тренування. Це було зроблено за рахунок заміни деяких вправ на гнучкість і силу, а також використання загальнотренувальних вправ, що були взяті із заминки і включені до комплексу лікувальної гімнастики, але виконувалися в іншій послідовності та з іншою спрямованістю.

Таким чином, знаючи проблемні місця дзюдоїстів, завдяки систематизації та оптимізації впровадили комплекс лікувальної гімнастики, зберігаючи цілісність тренувального процесу i виконання спеціальної тренувальної техніки.

Також для забезпечення кращої ефективності до реабілітаційних заходів залучили масаж і самомасаж комірцевої зони під час піків навантаження, а також після змагань для зменшення напруження м'язів шиї. У даному випадку переважно використовували точковий масаж і самомасаж.

Наступним завданням програми превентивної фрізичної реабілітації було впровадження комплексу лікувальної гімнастики для фрормування нормальної постави та правильного динамічного стереотипу. Особливу увагу приділяли новачкам, котрі тільки пізнають ази боротьби дзюдо. Для більшості з них різко зростає кількість фрізичного навантаження, а специфіка виконання тренувальних вправ може загострити вже наявні проблеми із поставою або стати основою для фрормування вертеброгенних порушень у майбутньому, особливо за наявності відповідних передумов. Отже, завданнями лікувальної гімнастики для цього контингенту були такі: 
- форомування навички правильної постави з урахуванням збільшеної кількості навантажень на м'язовий корсет хребта;

- профрілактика вертеброгенних порушень, що можуть бути спричинені спеціальним фрізичним навантаженням;

- навчання використанню фрізичних вправ з оздоровчою метою;

- становлення мотивацій та потреб у виконанні превентивних реабілітаційних заходів.

До комплексу лікувальної гімнастики увійшли дихальні та гімнастичні фрізичні вправи, що спрямовані задіяти всі відділи хребта, а також забезпечити гармонійний ріст і розвиток прилег-

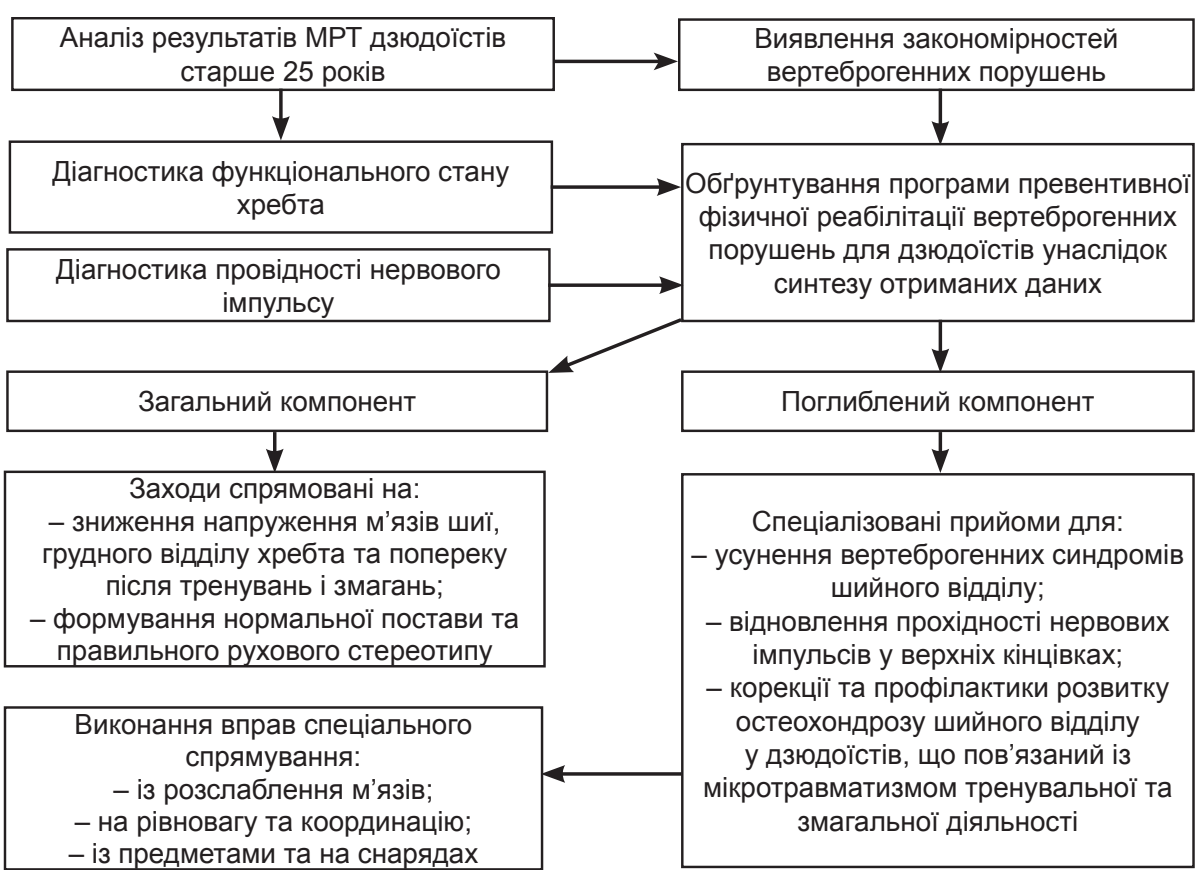

Рисунок 1 - Блок-схема технології корекційно-профрілактичного процесу для дзюдоїстів із використанням методів і засобів фрізичної реабілітації лих структурних елементів.

Для виконання вищезазначених завдань використовують загально-розвивальні вправи для всіх м'язових груп, що вже входять до тренувального процесу, а також спеціальні вправи: на накопичення м'язової пам'яті для фрормування правильної постави, на активізацію глибоких м'язів спини та шиї, на розслаблення та збільшення рухливості поясу верхніх кінцівок, а також поперекового відділу, з предметами та на рівновагу.

Спеціальні вправи проводять після блоку загальної фрізичної підготовки протягом 10 хв. Вони позитивно впливають на виконання спеціальної техніки дзюдо, особливо на засвоєння вправ на рівновагу та координацію. На цьому завершується загальний компонент програми превентивної фрізичної реабілітації вертеброгенних порушень у дзюдоїстів. Особливості застосування засобів фрізичної реабілітації, спрямованих на профрілактику вертеброгенних порушень у шийному відділі, буде висвітлено у поглибленому компоненті даної програми.

\section{Література}

1. Апанасенко Г. Л. Валеология: состояние и перспективы развития / Г. Л. Апанасенко, Л. А. Попова // Журн. АМН Украины. - 1997. - № 3. - С. 426-436.

2. Епифранов В. А. Восстановительное лечение при заболеваниях и повреждениях позвоночника / В. А. Епифранов, А. В. Епифранов. - М. : Медпресс-информ, 2008. - 384 с.

3. КнязеВа И. А. Применение методов биологической обратной связи для коррекции нарушения осанки и активной профилактики мышечного перенапряжения у спортсменов : дисс. на соискание ученой степени канд. мед.
Висновки і перспективи подальших пошуків у цьому напрямку. Незаперечним фрактом у спортивному травматизмі $\epsilon$ розвиток хронічних захворювань, що не дають змоги досягти максимальних результатів, а з часом призводять до погіршення якості життя. Для дзюдо характерне ураження хребта, а саме розвиток остеохондрозу шийного відділу із подальшими вертеброгенними порушеннями у вигляді різних синдромів.

У цій роботі представлено структуру програми превентивної фрізичної реабілітації вертеброгенних порушень шийного відділу для дзюдоїстів, вказано загальні задачі, спрямування та можливості її впровадження. Висвітлено загальний компонент програми.

Поглиблений компонент буде викладено у майбутніх публікаціях із зазначенням принципів, засобів і методів превентивної фрізичної реабілітації вертеброгенних порушень шийного відділу дзюдоїстів.

\section{References}

1. Apanasenko G. L., Popova L. A. (1997) Valeologiya: sostoyanie i perspektivy razvitiya [Valeology: status and prospects of development]. Zhurn. AMN Ukrainy, no 3, pp. 426436. (in Russian)

2. Yepifanov V. A., Yepifanov A. V. (2008) Vosstanovitelnoe lechenie pri zabolevaniyakh i povrezhdeniyakh pozvonochnika [Rehabilitative treatment during spine diseases and injuries]. M.: Medpress-inform (in Russian)

3. Knyazeva I. A. (2007) Primenenie metodov biologicheskoy obratnoy svyazi dlya korrektsii narusheniya 
наук : спец. 14.00.51 «Восстановительная медицина, лечебная физкультура и спортивная медицина, курортология и фризиотерапия» / И. А. Князева. - М., 2007. - 126 с.

4. КоВаленко О. Є. Віддалені неврологічні наслідки легких вертебральних травм / О. Є. Коваленко, Є. Л. Мачерет, А. І. Галуша / / Здоров'я України. - 2011. - № 2. - С. 9-11.

5. Колесниченко В. А. Вертебрологические аспекты спортивного отбора и ориентации спортсменов / В. А. Колесниченко, В. А. Стауде // Спорт. медицина. - К. : НУФВСУ, 2005. - № 1. - С. 171-175.

6. Мазенков А. А. Методика комплексного применения статических (изометрических) и динамических упражнений в физическом воспитании студентов: автореф. дисс. на соискание ученой степени канд. пед. наук / А. А. Мазенков. - Тюмень, 2003. - 21 с.

7. Макаилл Л. Лечебная гимнастика для спины и позвоночника / Л. Макгилл ; пер. с англ. В. Ф. Круглянский. Минск : Попурри, 2010. - 256 с.

8. Мартынихин В. С. Профилактика и физическая реабилитация остеохондроза поясничного отдела позвоночника в условиях тренировочного процесса у занимающихся конным спортом : автореф. : спец. 14.00 .51 / В. С. Мартынихин. М. : ВНИИ фриз. культуры и спорта, 2005. - 24 с.

9. Письменский В. В. Физиолого-биомеханическое обоснование коррекции функциональных нарушений опорно-двигательного аппарата у детей и подростков: автореф. дисс. на соискание учёной степени канд. биол. наук / В. В. Письменский. - Краснодар : Кубан. гос. ун-т фриз. культуры, спорта и туризма, 2004. - 120 с.

10.СоколоВа Н. И. Превентивная физическая реабилитация как стратегия профилактики хронических соматических заболеваний : дисс. д-ра наук по фриз. воспитанию и спорту : 24.00.03 / Н. И. Соколова. - К. : НУФВСУ, 2005. - 548 с.

11. Фурман Ю. Вдосконалення функціональної підготовленості плавців 13-14 років на етапі попередньої базової підготовки шляхом застосування методики ендогенно-гіпоксичного дихання та стимуляції анаеробних алактатних процесів енергозабезпечення / Ю. Фурман, І. Грузевич // Спорт. вісн. Придніпров'я. - Дніпропетровськ : Дніпропетр. держ. ін-т фріз. культури і спорту. - 2013. - Вип. 13. - С. 121-125.

12. Шевцов А. В. Функциональное состояние висцеральных систем организма спортсменов при немедикаментозном способе коррекции мышечно-тонической асимметрии паравертебральной зоны / А. В. Шевцов. - Челябинск : ГБОУ ВПО «Челябинская гос. мед. академия», 2012 - 323 с.

13. Qian M. The Effect of Rejuvenation Heat Treatments on the Repair Weldability of Wrought Alloy 718 / M. Qian, J. C. Lippold // Materials Science and Engineering A. 2003. - 340 (1-2): 225-231.

14. Shah S. A. «Treatment of Spinal Deformity in Cerebral Palsy». In The Growing Spine: Management of Spinal Disorders in Young Children / S. A. Shah , B. A. Akbarnia, M. Yazici, G. H. Thompson (eds). - Berlin Heidelberg : Springer-Verlag, 2011. - P. 229-239.

helenka_!@mail.ru

\section{Спортивна медицина і фізична реабілітація, №2, 2016}

osanki i aktivnoy profilaktiki myshechnogo perenapryazheniya u sportsmenov [Application of method of biological feedback for correcting posture disorders and active prevention of muscle overstrain in athletes] (PhD Thesis) (in Russian)

4. Kovalenko O. Ye., Macheret Ye. L., Halusha A. I. (2011) Viddaleni nevrolohichni naslidky lehkykh vertebralnykh travm [Remote neurologic consequences of light vertebral injuries]. Zdorovia Ukrainy, no 2, pp. 9-11. (in Ukrainian)

5. Kolesnichenko V. A., Staude V. A. (2005) Vertebrologicheskie aspekty sportivnogo otbora i orientatsii sportsmenov [Spine aspects of sports selection and orientation of athletes]. Sportivna meditsina, no 1, pp. 171-175. (in Russian)

6. Mazenkov A. A. (2003) Metodika kompleksnogo primeneniya staticheskikh (izometricheskikh) $i$ dinamicheskikh uprazhneniy $v$ fizicheskom vospitanii studentov [Methods of complex application of static (isometric) and dynamic exercises in student physical education] (PhD Thesis). Tyumen (in Russian)

7. Makgill L. (2010) Lechebnaya gimnastika dlya spiny i pozvonochnika [Back therapy training]. Minsk: Popurri (in Russian)

8. Martynikhin V. S. (2005) Profilaktika i fizicheskaya reabilitatsiya osteokhondroza poyasnichnogo otdela pozvonochnika $v$ usloviyakh trenirovochnogo protsessa u zanimayushchikhsya konnym sportom [Prevention and physical rehabilitation of lumbar osteochondrosis under conditions of training process] (PhD Thesis). M.: VNII fiz. kultury i sporta (in Russian)

9. Pismenskiy V. V. (2004) Fiziologo-biomekhanicheskoe obosnovanie korrektsii funktsionalnykh narusheniy opornodvigatelnogo apparata u detey i podrostkov [Physiological and biomechanical substantiation of correcting locomotorium functional disorders in children and adolescents] ( $\mathrm{PhD}$ Thesis). Krasnodar: Kuban. gos. un-t fiz. kultury, sporta i turizma (in Russian)

10. Sokolova N. I. (2005) Preventivnaya fizicheskaya reabilitatsiya kak strategiya profilaktiki khronicheskikh somaticheskikh zabolevaniy [Preventive physical rehabilitation as a strategy for preventing chronic somatic diseases] (PhD Thesis). K.: NUFVSU (in Russian)

11. Furman Yu., Hruzevych I. (2013) Vdoskonalennia funktsionalnoi pidhotovlenosti plavtsiv $13-14$ rokiv na etapi poperednoi bazovoi pidhotovky shliakhom zastosuvannia metodyky endohenno-hipoksychnoho dykhannia ta stymuliatsii anaerobnykh alaktatnykh protsesiv enerhozabezpechennia [Improvement of functional fitness of swimmers aged 1314 years at the stage of preliminary basic preparation by means of endogeneous-hypoxic breathing and simulation of anaerobic alactate processes of energy supply]. Sport. visn. Prydniprovia, vol. 13, pp. 121-125. (in Ukrainian)

12. Shevtsov A. V. (2012) Funktsionalnoe sostoyanie vistseralnykh sistem organizma sportsmenov pri nemedikamentoznom sposobe korrektsii myshechno-tonicheskoy asimmetrii paravertebralnoy zony [Functional state of athlete body visceral systems during drug-free correction of musclular tonic asymmetry of paravertebral zone]. Chelyabinsk: GBOU VPO "Chelyabinskaya gos. med. akademiya» (in Russian)

13. Qian M., Lippold J. C. (2003) The Effect of Rejuvenation Heat Treatments on the Repair Weldability of Wrought Alloy 718. M. Qian, Materials Science and Engineering A, 340 (1-2): 225-231.

14. Shah S. A., Akbarnia B. A., Yazici M., Thompson G. H. (2011) «Treatment of Spinal Deformity in Cerebral Palsy». In The Growing Spine: Management of Spinal Disorders in Young Children. Berlin Heidelberg: Springer-Verlag, pp. 229-239.

Надійшла 29.06.2016 